\title{
С.Е. Косілова
}

\section{АКУШЕРСЬКІ ТА ПЕРИНАТАЛЬНІ УСКЛАДНЕННЯ, ЯК ФАКТОРИ РИЗИКУ ЗАТРИМКИ РОСТУ ПЛОДА}

Вищий державний навчальний заклад України «Буковинський державний медичний університет», м. Чернівці

\begin{abstract}
Резюме. Затримка росту плода є однією з провідних причин перинатальної захворюваності та смертності, негативно віддзеркалюється на подальшому розвитку дитини і становленні усіх функцій іï організму. Недостатня ефективність існуючих засобів профілактики та лікування даної патології зумовлює подальші дослідження механізмів іiі формування. Для зниження перинатальної захворюваності велике значення має не тільки діагностика патологічних станів, що вже існують, але й можливість їх прогнозування. Тому, метою роботи було виявлення факторів ризику виникнення затримки росту плода. Проведено аналіз акушерської документації 100 жінок, вагітність яких ускладнилася затрим-
\end{abstract}

Вступ. Основним завданням акушерської практики є народження здорових дітей. Тому, ретельне вивчення патологічних станів, які впливають на стан внутрішньоутробного плода, та їм запобігання має провідне практичне значення. Велике значення в розвитку хронічних форм патології та дитячої інвалідності має затримка росту плода $[1,2,5,7]$. За даними літератури, у 3 $10 \%$ вагітних має місце затримка росту плода (ЗРП), а при антенатальній загибелі плода цей показник збільшується до 20 \% [1, 2, 3, 5]. Частота затримки росту плода в недоношених становить $15,7-22 \%[1,5]$. Дана патологія є однією 3 провідних причин перинатальної захворюваності і смертності, негативно відбивається на подальшому розвитку дитини і становленні всіх функцій іiі організму. Діти, народжені з ознакою затримки росту, потребують тривалого диспансерного спостереження i, за необхідності, проведення відповідної терапії $[1,2,3,6]$.

Недостатня ефективність існуючих засобів профілактики та лікування ЗРП зумовлює подальші дослідження патогенетичних механізмів формування даної патології. Для зниження перинатальної захворюваності велике значення має не тільки діагностика патологічних станів, що вже існують, але й можливість їх прогнозування [2, 3, 6, 8].

Чисельні вітчизняні та закордонні дослідження свідчать про те, що основну роль у патогенезі акушерських ускладнень відіграють порушення в системі гемостазу, особливо спадкові та набуті тромбофілії, які порушують функціювання захисних механізмів проти тромбозу, призводять до порушення інвазії трофобласту, плацентарної перфузії та розвитку акушерських ускладнень, у тому числі до затримки росту плода $[4,8]$.

Мета дослідження. Виявити фактори ризику виникнення затримки росту плода (ЗРП).

Матеріал і методи. 3 метою реалізації поставленої мети проведений ретроспективний аналіз 100 обмінних карт, історій пологів, карт роз(c) С.Є. Косілова, 2016 кою росту плода. 3'ясовано, що жінки з ускладненим акушерсько-гінекологічним анамнезом, із екстрагенітальною патологією складають групу ризику 3 розвитку даної патології. Ускладнений перебіг вагітності призводить до зниження компенсаторно-пристосувальних реакцій матері та плода, затримки його росту. Пологи в жінок із даною патологією характеризуються великою кількістю ускладнень, народженням дітей із гіпоксичним ураженням центральної нервової системи (32\%), дихальними розладами (7\%).

Ключові слова: вагітність, затримка росту плода, перинатальні фактори ризику.

витку новонароджених, жінок, що народили дітей із масо-ростовими параметрами, нижчими за норму. Ці вагітні склали основну групу. Групу контролю склали 30 жінок, що народили здорових дітей.

Діагноз ЗРП встановлювали за даними УЗД, проведеного в термін 28-34 тижні вагітності,за відставання фетометричних показників на два i більше тижнів від гестаційного терміну. Постнатальним критерієм ЗРП вважали масу тіла новонароджених нижче 10-го процентиля для даного гестаційного віку.

У групах вагітних зі ЗРП ультразвукову фотометрію проводили в динаміці кожні два тижні. Доплерометрію кровотоку проводили один раз на тиждень, за необхідності (патологічні біофізичні показники) - щонайменш один раз на два дні. Фетальний кардіомоніторинг виконували щоденно.

Результати дослідження та їх обговорення. Вік жінок в обох групах коливався від 18 до 40 років, середнє значення склало $26,6 \pm 6$. Кількість першо- і повторнонароджуючих в обох групах була однаковою і становила 60 \% і 40 \% відповідно. Мимовільне переривання вагітності в ранні терміни мало місце у 20 (20\%) жінок основної групи і в $3(10 \%)$ - у контрольній $(\mathrm{p}<0,05)$. Привертає увагу те, що на відміну від контрольної групи, в 11 обстежених основної групи було два і більше викидні. Завмерла вагітність в анамнезі відмічалась, також, тільки в жінок основної групи (4 \%). Передчасними пологами попередні вагітності завершились у 6 (6 \%) жінок основної групи і в $1(3,3 \%)$ - у контрольній, кесаревим розтином - у 5 (5\%) основної групи. Антенатальна загибель плода в анамнезі (4 \%) і рання неонатальна смертність (2\%) мала місце тільки в основній групі.

Відомо, що несприятливий вплив на перебіг вагітності, ріст плода здійснює екстрагенітальна патологія, іiі тривалість і тяжкість перебігу. Під час аналізу індивідуальних карт вагітності з'ясо- 
вано: в основній групі вади серця, ревматичні ураження мали місце у 8 \% обстежених, гіпертензивні розлади - у $20 \%$, нейроциркуляторна дистонія за гіпертонічним типом - у 12 \%. Варикозне розширення вен - у 12 (12\%) вагітних основної групи і в $1(3,3 \%)$ - у контрольній $(\mathrm{p}<0,05)$. За даними літератури несприятливий вплив підвищеного артеріального тиску пояснюється зміною в стромі ворсин, появою порушень мікроциркуляції, стазом, агрегацією еритроцитів і тромбоцитоутворенням. Це призводить до порушення метаболічної та транспортної функції плаценти, погіршення газообміну i постачання до плода харчових речовин $[1,3,6,8]$. Наявність TORCHінфекції виявлено у 44 (44 \%) обстежених основної групи і в $5(16,5 \%)$ - у контрольній $(\mathrm{p}<0,05)$. Хронічний пієлонефрит спостерігався у 24 (24\%) жінок основної групи і у $2(6,6$ \%) - у контрольній $(\mathrm{p}<0,05)$. Запальні захворювання нирок призводять до порушення дозрівання і запальним змінам у плаценті, що зумовлює порушення іiі функції $[2,3]$. Привертає увагу те, що в основній групі було досить багато жінок (15\%) 3 надмірною масою тіла. У той час як у контрольній групі надмірну масу тіла мала тільки одна жінка $(3,3$ \%), $(\mathrm{p}<0,05)$. А надмірна маса тіла може бути одним iз проявів метаболічного синдрому, який супроводжується гіперкоагуляцією, зниженням фібринолітичної активності крові. Це призводить до порушення інвазії трофобласта і розвитку плаценти $[1,4,7]$. Із соціально-економічних факторів певне значення мав хронічний алкоголізм і наркоманія.

Ускладнений перебіг вагітності також здійснює негативний вплив на внутрішньоутробний ріст плода. Так, до факторів ризику виникнення ЗРП слід віднести блювання вагітних (21 \% в основній групі та 13,3 \% - у контрольній, $\mathrm{p}<0,05)$, загрозу переривання вагітності (43\% в основній групі та 19,9\% - у контрольній, $р<0,05)$, гестаційну анемію (47 \% в основній групі та $16,6 \%$ - у контрольній, $\mathrm{p}<0,05)$, прееклампсію різного ступеня (30\% в основній групі та $3,3 \%$ у контрольній, $\mathrm{p}<0,05)$, передлежання плаценти (9 \% в основній групі та 3,3\% - у контрольній, $(\mathrm{p}<0,05)$, імуноконфлікт під час вагітності (8\% в основній групі та 3,3\% - у контрольній, $(\mathrm{p}<0,05)$. Плацентарна дисфункція мала місце в $96 \%$ жінок основної групи і в $16,5 \%$ - у контрольній. Виявлена гормональна недостатність у 70 \% жінок основної групи і в $6,6 \%$ - у контрольній (зниження вмісту прогестерону і плацентарного лактогену, підвищення ДЕА).

Аналіз результатів пологів показав, що в основній групі був великий відсоток передчасних пологів (31%). Їхні основні причини: передчасне відшарування плаценти, прееклампсія середнього і тяжкого ступеня, передчасне відходження навколоплідних вод. Пологорозрішення оперативним шляхом відбулося у $20 \%$ жінок основної групи і 3,3 \% - у контрольній $(\mathrm{p}<0,05)$. Показами до оперативного розродження були: передчасне відшарування нормально розташованої плаценти (4 \%), гострий дистрес плода (2 \%), прееклампсія середнього і тяжкого ступеня без ефекту від лікування (6 \%), рубець на матці (4 \%), поєднані покази (3\%). Середня маса тіла і зріст новонароджених статистично достовірно були нижчими в основній групі порівняно 3 групою контролю:

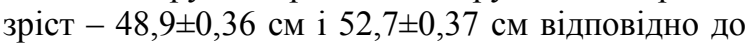
груп, ( $<00,05)$; маса тіла - 2476 236,65 г і 3323$\pm 64,51$ г відповідно до груп $(\mathrm{p}<0,05)$. Середня оцінка новонароджених за шкалою Апгар на першій і п’ятій хвилинах була нижчою в основній групі, ніж у групі контролю і складала на першій

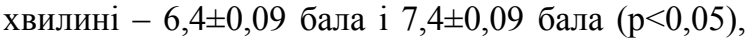
на п'ятій хвилині - 7,5 $\pm 0,06$ бала і $8,4 \pm 0,07$ бала $(\mathrm{p}<0,05)$ відповідно до груп. Необхідно зазначити, що 32 новонароджених основної групи мали ознаки гіпоксичного ураження центральної нервової системи, 7 \% - синдром дихальних розладів, $12 \%$ - були переведені на наступний етап надання медичної допомоги, 3 \% померли в ранньому неонатальному періоді.

Результати гістологічного дослідження плацент від вагітних із ЗРП досить різноманітні від невеликих інволютивно-дистрофічних змін до явищ декомпенсованої плацентарної дисфункції, що зумовлено поліетіологічністю факторів, які впливають на розвиток затримки росту плода, тривалістю їх діï, станом компенсаторнопристосовчих механізмів матері і плода $[1,3,7]$. У більшості випадків спостерігали невідповідність ступеня зрілості плаценти до терміну гестації, склероз строми ворсин, надмірне відкладання фібриноїду у міжворсинчатому просторі, кальциноз термальних ворсин.

\section{Висновки}

1. Жінки зі звичним невиношуванням вагітності, завмерлою вагітністю та антенатальною загибеллю плода в анамнезі складають групу ризику з виникнення затримки росту плода.

2. Особливе місце у виникненні затримки росту плода посідає патологія серцево-судинної системи, захворювання нирок, метаболічні порушення.

3. Ускладнений перебіг вагітності призводить до зниження компенсаторно-пристосувальних реакцій матері та плода і виникненню затримки росту плода.

4. Пологи в жінок із затримкою росту плода характеризуються великою кількістю ускладнень, народженням дітей 3 гіпоксичним ураженням центральної нервової системи, дихальними розладами, мертвонародженням.

Перспективи подальших досліджень. Виявлення факторів ризику виникнення затримки росту плода, своєчасна їх діагностика та лікування дозволить знизити розвиток тяжких форм ЗРП, забезпечить народження здорових дітей.

\section{Література}

1. Бінковська А.М. Стан фетоплацентарного комплексу при синдромі затримки росту плода/ А.М. Бінковсь- 
ка // Педіатрія, акуш. і гінекол. - 2012. - № 1. C. 35-38.

2. Воронин К.В. Акушерские и перинатальные осложнения при задержке внутриутробного развития плода / К.В. Воронин, Т.А. Лоскутова // Зб. наук. пр. Асоц. акуш.-гінекол. України. - К., 2011. - С. 61-64.

3. Дашкевич В.С. Плацентарна недостатність: сучасні аспекти патогенезу, діагностика, профілактика та лікування / В.С. Дашкевич, С.М. Янюта, Т.В. Коломійченко // Мистецтво лікування. - 2009. - № 4. C. $22-25$.

4. Пшеничникова Е.Б. Метаболический синдром и тромбофилия - состояние высокого риска у беременных / Е.Б. Пшеничникова, Т.Б. Пшеничникова, А.Д. Макацария // РМЖ. Спец. выпуск. - 2011. - С. 53-60
5. Фролова О.Г. Статистика перинатального періоду / О.Г. Фролова, Т.Н. Пугачева, В.В. Гудимова // Акуш. и гинекол. - 2012. - № 5. - С. 36-38.

6. Янюта С.М. Діагностика критичного стану плода / С.М. Янюта, В.П. Присяжнюк, О.С. Янюта // Зб. наук. пр. Асоц. акуш.-гінекол. України. - К., 2012. C. $456-462$.

7. Gude N.M. Autacoid interaction in the regulation of blood flow in the human placenta / N.M. Gude, R.G. King, S.P. Brennecke // Semin. Perinatol. - 2007. - № 3. P. 196-201.

8. Redman C.W. The pathogenesis of preeclampsia / C.W. Redman, I.L. Sargent // Gynekol. Jbstet. Fertil. 2008. - Vol. 29, № 7-8. - P. 518-522.

\section{АКУШЕРСКИЕ И ПЕРИНАТАЛЬНЫЕ ОСЛОЖНЕНИЯ, КАК ФАКТОРЫ РИСКА ЗАДЕРЖКИ РОСТА ПЛОДА}

\section{С.Е. Косилова}

Резюме: Задержка роста плода является одной из ведущих причин перинатальной заболеваемости и смертности, отрицательно влияет на дальнейшее развитие ребёнка и становление всех функций его организма. Недостаточная эффективность существующих способов профилактики и лечения данной патологии обуславливает дальнейшие исследования механизмов её формирования. Для снижения перинатальной заболеваемости большое значение имеет не только диагностика патологических состояний, которые уже существуют, но и возможность их прогнозирования. Поэтому, целью работы было изучение факторов риска развития задержки роста плода. Проведен анализ акушерской документации 100 женщин, беременность которых осложнилась задержкой роста плода. Установлено, что женщины с осложненным акушерско-гинекологическим анамнезом, с экстрагенитальной патологией составляют группу риска по развитию данной патологии. Осложненное течение беременности приводит к снижению компенсаторно-приспособительных реакций матери и плода, задержке его роста. Роды у женщин с данной патологией характеризуются большим количеством осложнений, рождением детей с гипоксическим поражением центральной нервной системы (32\%), дыхательными расстройствами (7 \%).

Ключевые слова: беременность, задержка роста плода, перинатальные факторы риска.

\section{OBSTETRICAL AND PERINATAL COMPLICATIONS AS RISK FACTORS OF FETAL GROWTH RETARDATION}

\section{S.Y. Kosilova}

Abstract. Fetal growth retardation is one of the leading causes of perinatal sickness and mortality rates, having a negative impact upon further development of an infant and all the body functions. Insufficient efficacy of the current means of prevention and treatment of this pathology stipulates further studies of the mechanisms of its formation. Not only diagnostics of pathological conditions is of great importance to reduce existing perinatal sickness but the possibility to prognosticate as well. Therefore, the objective of the research was to study risk factors of fetal growth retardation. Obstetrical documents of 100 women with their pregnancy complicated by fetal growth retardation have been analyzed. The women with complicated obstetrical-gynecological anamnesis and extragenital pathology have been found to constitute a risk group concerning the development of this pathology. Complicated course of pregnancy results in the decrease of compensatoryadaptive reactions of the mother and fetus, and retardation of its growth. The labor in women with this pathology is characterized by a number of complications, birth of infants with hypoxic lesions of the central nervous system (32\%), and respiratory disorders $(7 \%)$.

Key words: pregnancy, fetal growth retardation, perinatal risk factors.

Higher State Educational Institution of Ukraine "Bukovinian State Medical University" (Chernivtsi) 